\title{
Landfill Leachate Toxicity Removal in Combined Treatment with Municipal Wastewater
}

\author{
J. Kalka \\ Environmental Biotechnology Department, Silesian University of Technology, 44100 Gliwice, Poland \\ Correspondence should be addressed to J. Kalka, joanna.kalka@polsl.pl
}

Received 30 October 2011; Accepted 9 January 2012

Academic Editor: Kuan F. Chang

Copyright ( $\odot 2012$ J. Kalka. This is an open access article distributed under the Creative Commons Attribution License, which permits unrestricted use, distribution, and reproduction in any medium, provided the original work is properly cited.

Combined treatment of landfill leachate and municipal wastewater was performed in order to investigate the changes of leachate toxicity during biological treatment. Three laboratory A2O lab-scale reactors were operating under the same parameters (Q-8.5$10 \mathrm{~L} / \mathrm{d}$; HRT-1.4-1.6 d; MLSS 1.6-2.5 g/L) except for the influent characteristic and load. The influent of reactor I consisted of municipal wastewater amended with leachate from postclosure landfill; influent of reactor II consisted of leachate collected from transient landfill and municipal wastewater; reactor III served as a control and its influent consisted of municipal wastewater only. Toxicity of raw and treated wastewater was determinted by four acute toxicity tests with Daphnia magna, Thamnocephalus platyurus, Vibrio fischeri, and Raphidocelis subcapitata. Landfill leachate increased initial toxicity of wastewater. During biological treatment, significant decline of acute toxicity was observed, but still mixture of leachate and wastewater was harmful to all tested organisms.

\section{Introduction}

Waste volume is growing faster than the world's population, and management of wastes is a matter of considerable human concern $[1,2]$. Recycling and recovery of materials and energy are encouraged so as to safeguard natural resources and obviate wasteful use of land [3]. Nevertheless landfilling is still widely accepted and popular method for the ultimate disposal of solid waste material. It is estimated that $90 \%$ of solid waste in Poland is disposed of in landfill sites [2]. The internal biochemical decomposition processes taking place within a landfill play a crucial role in determining potential adverse impacts that landfills may have during and beyond its active life. Rainfall and other precipitation percolating through layers of waste may dissolve and wash out products of biochemical processes creating landfill leachate. Many studies have shown that landfill leachate consisted of different groups of pollutants such as organics: alkenes, aromatic hydrocarbons, acids, esters, alcohols, hydroxybenzene, amides, and so forth, as well as ammonia nitrogen and heavy metals. Some authors report that more than 190 substances were identified in leachate, making barely $1 \%$ of materials calculated from total organic carbon concentration
[4]. Chemical composition of leachate changes with the time span of landfill operation. Typical leachate COD for the transient landfills ( $2-5$ years of operation) is 500 $10000 \mathrm{mg} / \mathrm{L}$, while the same parameter for old landfill leachate is less than $500 \mathrm{mg} / \mathrm{L}$ [5]. Leachate may endanger aquatic environment due to uncontrolled overflow, subsidence, and infiltration [6-9]. Due to its high organic matter content, landfill leachate was the subject of many research experiment involving advanced oxidation processes (e.g., Fenton, electro-Fenton) as a treatment method [10, 11]. However, the most common practice to avoid risk of contamination is to discharge leachate into wastewater stream and subsequent treatment in wastewater treatment plant. Refractory micro- and macropollutants may pass biological treatment plant unchanged and contribute to still high toxicity of the effluent. It is well known that toxicity of environmental samples (like wastewater or leachate) is a consequence of numerous contaminants, their synergistic or antagonistic effects, and physicochemical properties. As the composition of leachate is unstable during the landfill operation period, adverse effect of leachate is also variable in different operational period. The aim of the present study was to investigate the change of toxicity of landfill leachate 


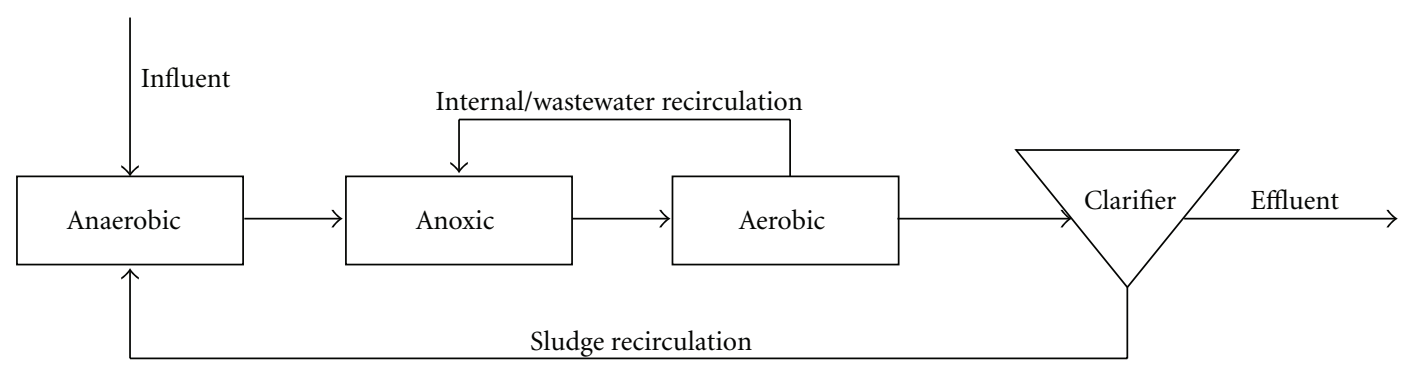

Figure 1: Scheme of A2O-activated sludge system.

in function of the landfill age. Leachate was sampled from landfills of different age (I: postclosure landfill; II: new landfill 2 years of operation), and its toxicity was tested towards selected aquatic organisms. Leachate (separately) was subsequently mixed in different ratio with municipal wastewater and treated in lab-scale A2O-activated sludge systems. Both before and after biological treatment, toxicity of treated mixture was tested.

\section{Material and Methods}

2.1. Leachate and Wastewater. Leachate was collected from the Municipal Solid Waste Landfill in Zabrze (Poland). There are two sections in Zabrze Landfill: I: the "old," reclaimed section; II: the "new" one receiving municipal waste since 2007. The landfill leachate from both sections is collected separately in equalization basins and recirculated to the waste dump. Excess of leachate is pumped to the sewage collection system. The leachate flow is $80 \mathrm{~m}^{3}$ from each section daily. Samples were collected from the equalization basins.

Wastewater was collected from wastewater treatment plant in Zabrze-Mikulczyce (Poland). The place for wastewater collection was selected to ensure lack of earlier wastewater contamination by leachate. The daily flow of wastewater is average $5000 \mathrm{~m}^{3} / \mathrm{d}$.

2.2. Treatment. A2O-activated sludge systems were composed of an anaerobic/anoxic/aerobic process with simultaneous nitrification-denitrification and biological phosphorus removal. Each system composed of three separate reactors with the following working volumes: anaerobic $2 \mathrm{~L}$, anoxic $5 \mathrm{~L}$, aerobic $7 \mathrm{~L}$ (Figure 1).

The experiment was carried out in three activated sludge A2O systems: I, II, and III. Influent of system I consisted of mixture of wastewater and "old" landfill leachate. Influent of system II consisted of mixture of wastewater and new landfill leachate. System III served as a control and was fed with municipal wastewater. The scheme of influents composition in different periods of experiment was presented in Table 1.

All systems were operated under the same technical parameters (Table 2) except for influent characteristic and load.

The reactors were inoculated with an activated sludge sampled from municipal wastewater treatment plant. Activated sludge in reactors I and II was acclimated to the increasing concentration of landfill leachate in the influent ( 1 and $10 \%)$. Some earlier study showed that median share
TABLE 1: Composition of influent of systems I, II, and III.

\begin{tabular}{llcc}
\hline System & $\begin{array}{c}\text { Type of } \\
\text { landfill }\end{array}$ & $\begin{array}{c}\text { Volume of leachate } \\
{[\%](\mathrm{v} / \mathrm{v})}\end{array}$ & $\begin{array}{c}\text { Volume of wastewater } \\
{[\%](\mathrm{v} / \mathrm{v})}\end{array}$ \\
\hline I & Old & 1 & 99 \\
\multirow{2}{*}{ II } & \multirow{2}{*}{ New } & 10 & 90 \\
\multirow{2}{*}{ III } & & 10 & 99 \\
\hline
\end{tabular}

TABLE 2: Operational parameters of activated sludge systems I, II, and III.

\begin{tabular}{lccccc}
\hline Parameter & Unit & System & Range & Average \pm SD & Median \\
\hline \multirow{4}{*}{$\begin{array}{l}\text { Sludge } \\
\text { loading }\end{array}$} & g COD/ & I: $10 \%$ & $0.11-0.15$ & $0.11 \pm 0.02$ & 0.11 \\
rate & g MLSS·d & II: $1 \%$ & $0.07-0.236$ & $0.08 \pm 0.02$ & 0.10 \\
& & II: $10 \%$ & $0.08-0.23$ & $0.15 \pm 0.03$ & 0.17 \\
& & III & $0.06-0.175$ & $0.09 \pm 0.04$ & 0.06 \\
MLSS & g/L & I & & & \\
& & II & $1.6-2.5$ & $2.0 \pm 0.2$ & 2.0 \\
& & III & & & \\
Q & L/d & I & & & \\
& & II & $8.5-10.0$ & $9.5 \pm 0.5$ & 9.7 \\
& & III & & & \\
HRT & d & I & & $1.5 \pm 0.1$ & 1.4 \\
& & II & $1.4-1.6$ & $1.6 \pm 0.4$ & 1.5 \\
& & III & & $1.5 \pm 0.1$ & 1.5 \\
\hline
\end{tabular}

SD: standard deviation; number of measurements $n=16$; time-dependent variation caused by unstable composition of influent.

COD: chemical oxygen demand.

MLSS: activated sludge concentration.

Q: wastewater flow.

HRT: hydraulic retention time.

of landfill leachate in wastewater stream should be at 5\% $(\mathrm{v} / \mathrm{v})$ level $[12,13]$. It was, therefore, decided that final concentration of landfill leachate in present study should not exceed $10 \%(\mathrm{v} / \mathrm{v})$. After the acclimation period, systems had been operated for 8 weeks with $1 \%$ of leachates in influent. Samples for chemical analysis as well as toxicity testing were collected from average daily sample of influent/effluent. After that, leachate concentration was gradually increased to $10 \%$. 
TABLE 3: Characteristic of "old" landfill leachate (nondiluted).

\begin{tabular}{lcccc}
\hline Parameter & Unit & Range & Average $\pm \mathrm{SD}^{*}$ & Median \\
\hline TOC & $\mathrm{mg} / \mathrm{L}$ & $309-352$ & $327 \pm 21$ & 324 \\
COD & $\mathrm{mg} / \mathrm{L}$ & $381-435$ & $403 \pm 19$ & 400 \\
BOD & $\mathrm{mg} / \mathrm{L}$ & $120-150$ & $134 \pm 11$ & 130 \\
N NH4 & $\mathrm{mg} / \mathrm{L}$ & $26-60$ & $43 \pm 10$ & 52 \\
\hline
\end{tabular}

*SD: standard deviation; number of measurements $n=16$; timedependent variation of parameters value was caused by unstable composition of leachate.

TABLE 4: Characteristic of "new" landfill leachate (nondiluted).

\begin{tabular}{lcccc}
\hline Parameter & Unit & Range & Average \pm SD $^{*}$ & Median \\
\hline TOC & mg/L & $1460-2300$ & $1950 \pm 350$ & 2010 \\
COD & mg/L & $1873-3600$ & $2560 \pm 615$ & 2330 \\
BOD & $\mathrm{mg} / \mathrm{L}$ & $150-273$ & $210 \pm 55$ & 210 \\
N NH4 & $\mathrm{mg} / \mathrm{L}$ & $971-1250$ & $1100 \pm 92$ & 1200 \\
\hline
\end{tabular}

*SD: standard deviation; number of measurements $n=16$; time-dependent variation of parameters value was caused by unstable composition of leachate.

2.2.1. Chemical Analysis. Ammonium nitrogen as well as organic nitrogen was measured with Kjeltec 1026 analyzer. Chemical and biological oxygen demands (COD and BOD) were determined by standard methods $[14,15]$. Chemical analysis were performed two times a week during 26 weeks research period.

2.3. Bioassays. Whole effluent toxicity tests were performed which means that the aggregate toxic effect of respectively influent or effluent was measured directly by a toxicity test.

Following tests were proposed for toxicity evaluation.

Vibrio Fischeri Luminescence Inhibition-Microtox [16]. The test was carried out in the Microtox M500 toxicity analyzer according to the standard procedure [16], which is in accordance with ISO-DIN 38412 Part 34, 9/91. The lyophilized bacteria Vibrio fischeri were purchased from Azur Environmental (Carlsbad, CA, USA). As a diluents, $2 \% \mathrm{NaCl}$ was used. As the samples of wastewater were coloured, light absorbances were measured at $490 \mathrm{~nm}$ and colour correction procedure was applied.

Vibrio fischeri luminescence inhibition test was performed three times.

Daphnia Magna Immobilisation Test [17]. Tests were carried out with neonates $(<24 \mathrm{~h})$. Five test dilutions were prepared in a $50 \%$ dilution series for each sample with three replicates of seven animals. The test volume was $20 \mathrm{~mL}$. The animals were not fed during the experiment. Each test had a duration $48 \mathrm{~h}$; the temperature was $24 \pm 1^{\circ} \mathrm{C}$. After an exposure, the number of immobile daphnids for each dilution was recorded. Daphnia magna immobilization test was performed five times.
Thamnocephalus Platyurus Acute Toxicity Test [18]. Tests were carried out according to the MicroBioTest Standard Operational Procedure. Readily hatched organisms were used for the test. Five test dilutions were prepared in a 50\% dilution series.

Each sample was with 3 replicates of 10 animals in disposable multiwell test plates. Test volume was $1 \mathrm{~mL}$ per well.

After $24 \mathrm{~h}$ in a $25^{\circ} \mathrm{C}$ incubator in the dark, the number of dead crustaceans was recorded. Thamnocephalus platyurus acute toxicity test was performed five times.

Freshwater Algal Growth Inhibition Test with Unicellular Green Algae [19]. Exponentially growing Raphidocelis subcapitata were exposed to the test sample in batch cultures over a period of 72 hours in $24 \pm 1^{\circ} \mathrm{C}$. The biomass in the control cultures increased exponentially by a factor of at least 16 . Five test dilutions were prepared in a $50 \%$ dilution series with an initial biomass concentration $1 \times 10^{4}$ cells $/ \mathrm{mL}$. Each sample was with 3 replicates; growth inhibition test was performed five times.

\section{Results}

3.1. Leachate Characteristic. Chemical parameters of leachate from both sampling sites are presented in Tables 3 and 4 .

3.2. Biological Treatment. Biological treatment of leachate has been shown to be effective in removing organic and nitrogenous matter from immature effluent characterized by high $\mathrm{BOD} / \mathrm{COD}$ ratio $[1,2]$. In present study biodegradability factor (BOD/COD ratio) of influents containing $1 \%$ of leachate was 0.8 and 0.6 for system I and II, respectively. $\mathrm{BOD} / \mathrm{COD}$ ratio of wastewaters (system III) was 0.8 . It might be, therefore, concluded that, despite $1 \%$ amendment with landfill leachate, influent of system I was similarly prone to biological degradation as wastewater (Table 5). The effluents of systems, enriched by leachate (I and II) as well as wastewater treated in system III, met the quality standards described for wastewaters introduced to surface waters or ground $[20,21]$.

Effective ammonia and organic nitrogen removal was also observed in all three systems. Removal efficiency was within the range $85-99 \%$.

$10 \%$ amendment of leachate in wastewater stream decreased biodegradability of influent of system II (Table 5). $\mathrm{BOD} / \mathrm{COD}$ ratio decreased to 0.5 for system II and remained at 0.8 level for systems I and III. Lower biodegradability of wastewater mixed with $10 \%$ of new landfill leachate resulted in high content of organic substances in effluent II (Table 6). Removal of organic content in influents of systems I and III reached, respectively, 94 and 98\% BOD (78 and 83\% COD. The effluent of systems enriched by new landfill leachate did not meet the quality standards described for wastewaters introduced to surface or ground waters [20,21].

Combined treatment of landfill leachate and municipal wastewater was also investigated by Diamadopoulos et al. [22] in sequencing batch reactor. Parameters of the process were similar to those in the present study. The authors 
TABLE 5: Chemical characteristics of raw and treated wastewater (1\% of leachate in influent I and II).

\begin{tabular}{|c|c|c|c|c|c|c|c|c|c|}
\hline \multicolumn{2}{|c|}{ Parameter } & Unit & \multirow{2}{*}{$\begin{array}{c}\text { Range } \\
265-346\end{array}$} & \multirow{2}{*}{$\begin{array}{r}\text { Average } \pm \text { SD } \\
\text { Influent } \\
314 \pm 41\end{array}$} & \multirow{2}{*}{$\begin{array}{c}\text { Percentile } 80 / 100 \\
344\end{array}$} & \multirow{2}{*}{$\begin{array}{l}\text { Range } \\
57-124\end{array}$} & \multirow{2}{*}{$\begin{array}{c}\text { Average } \pm \text { SD } \\
86 \pm 24\end{array}$} & \multirow{2}{*}{$\begin{array}{l}\text { Percentile } 80 / 100 \\
\text { Effluent } \\
106\end{array}$} & \multirow{2}{*}{$\begin{array}{c}\text { Mean removal [\%] } \\
72\end{array}$} \\
\hline & I & & & & & & & & \\
\hline \multirow[t]{3}{*}{ COD } & II & $\mathrm{mg} / \mathrm{dm}^{3}$ & $213-486$ & $316 \pm 84$ & 346 & $15-142$ & $112 \pm 38$ & 138 & 64 \\
\hline & III & & $153-356$ & $222 \pm 71$ & 263 & $46-90$ & $65 \pm 15$ & 80 & 83 \\
\hline & I & & $230-270$ & $248 \pm 15$ & 246 & $5-10$ & $8 \pm 3$ & 10 & 97 \\
\hline \multirow[t]{3}{*}{ BOD } & II & $\mathrm{mg} / \mathrm{dm}^{3}$ & $180-200$ & $190 \pm 10$ & 190 & $10-20$ & $13 \pm 6$ & 10 & 93 \\
\hline & III & & $160-200$ & $180 \pm 20$ & 240 & $10-20$ & $13 \pm 6$ & 16 & 93 \\
\hline & I & & $106-151$ & $139 \pm 21$ & 152 & $19-34$ & $21 \pm 6$ & 26 & 85 \\
\hline \multirow[t]{3}{*}{$\mathrm{N}_{\mathrm{og}}$} & II & $\mathrm{mg} / \mathrm{dm}^{3}$ & $87-226$ & $161 \pm 68$ & 217 & $1-9$ & $3 \pm 2$ & 4 & 98 \\
\hline & III & & $73-181$ & $116 \pm 40$ & 150 & $1-4$ & $2 \pm 1$ & 1.0 & 99 \\
\hline & I & & $98-124$ & $97 \pm 10$ & 118 & $1-3$ & $3 \pm 2$ & 5 & 97 \\
\hline \multirow[t]{2}{*}{ N-NH4 } & II & $\mathrm{mg} / \mathrm{dm}^{3}$ & $85-177$ & $128 \pm 29$ & 154 & $1-9$ & $2 \pm 2$ & 4 & 98 \\
\hline & III & & $53-131$ & $78 \pm 20$ & 87 & $0-3$ & $1 \pm 1$ & 2 & 99 \\
\hline
\end{tabular}

TABLE 6: Chemical characteristics of raw and treated wastewater ( $10 \%$ of leachate in influent I and II).

\begin{tabular}{|c|c|c|c|c|c|c|c|c|c|}
\hline \multicolumn{2}{|c|}{ Parameter } & Unit & \multirow{2}{*}{$\begin{array}{c}\text { Range } \\
300-410\end{array}$} & \multirow{2}{*}{$\begin{array}{r}\text { Average } \pm \text { SD } \\
\text { Influent } \\
348 \pm 47\end{array}$} & \multirow{2}{*}{$\begin{array}{c}\text { Percentile } 80 / 100 \\
390\end{array}$} & \multirow{2}{*}{$\begin{array}{l}\text { Range } \\
43-114\end{array}$} & \multirow{2}{*}{$\begin{array}{c}\text { Average } \pm \text { SD } \\
74 \pm 24\end{array}$} & \multirow{2}{*}{$\begin{array}{l}\text { Percentile } 80 / 100 \\
\text { Effluent } \\
90\end{array}$} & \multirow{2}{*}{$\begin{array}{c}\text { Mean removal [\%] } \\
78\end{array}$} \\
\hline & I & & & & & & & & \\
\hline \multirow[t]{3}{*}{ COD } & II & $\mathrm{mg} / \mathrm{dm}^{3}$ & $281-650$ & $460 \pm 95$ & 520 & $62-233$ & $150 \pm 45$ & 182 & 67 \\
\hline & III & & $257-362$ & $316 \pm 49$ & 361 & $34-83$ & $55 \pm 22$ & 70 & 83 \\
\hline & I & & $240-280$ & $262 \pm 18$ & 280 & $10-20$ & $17 \pm 6$ & 20 & 94 \\
\hline \multirow[t]{3}{*}{ BOD } & II & $\mathrm{mg} / \mathrm{dm}^{3}$ & $240+270$ & $250 \pm 17$ & 258 & $10-20$ & $10 \pm 0$ & 10 & 96 \\
\hline & III & & $240-280$ & $264 \pm 17$ & 272 & $0-10$ & $6.0 \pm 4$ & 8 & 98 \\
\hline & I & & $87-151$ & $109 \pm 41$ & 133 & $8-23$ & $16 \pm 6$ & 21 & 86 \\
\hline \multirow[t]{3}{*}{$\mathrm{N}_{\mathrm{og}}$} & II & $\mathrm{mg} / \mathrm{dm}^{3}$ & $135-380$ & $277 \pm 66$ & 315 & $4-9$ & $6 \pm 2$ & 6 & 98 \\
\hline & III & & $73-296$ & $150 \pm 71$ & 200 & $0-13$ & $6 \pm 4$ & 10 & 96 \\
\hline & $\mathrm{I}$ & & $26-70$ & $53 \pm 16$ & 61 & $2-10$ & $5 \pm 3$ & 8 & 90 \\
\hline \multirow[t]{2}{*}{ N-NH4 } & II & $\mathrm{mg} / \mathrm{dm}^{3}$ & $128-255$ & $200 \pm 33$ & 222 & $3-16$ & $6 \pm 3$ & 7 & 97 \\
\hline & III & & $80-160$ & $120 \pm 26$ & 136 & $2-10$ & $5 \pm 4$ & 8 & 96 \\
\hline
\end{tabular}

reported that efficiency of BOD removal was 95\%, but still quality criteria were not met.

Several authors revealed also the possibility of leachate treatment in combining aerobic-anaerobic conditions, which allowed to perform treatment with higher organic loading rates [9, 23]. Gomec et al. [24] reported combined anaerobic wastewater sludge stabilisation and treatment of landfill leachate in UASB reactor. $1 \%$ of young leachate amendment improved COD removal rate as well as biogas production.

Organic and ammonia nitrogen was effectively removed in systems I, II, and III-removal efficiency was as high as 86, 98 , and 96 percent, respectively.

3.3. Toxicity Testing. The results of toxicity tests were presented in Table 7 as median effect or inhibition concentrations $\left(\mathrm{EC} / \mathrm{IC}_{50}\right)$.

Toxicity of new landfill leachate was significantly higher than toxicity attributed to old landfill leachate. The overall toxicity of old leachate samples allowed to classify it as toxic, while new landfill leachate toxicity was more than ten times higher, and new leachate was classified as very toxic [25].

The results of toxicity tests were also examined for environmental relevance by calculating toxicity units (TUs) as reported in Tables 8 and 9. The toxic unit of an effluent is the inverse of its $\mathrm{EC}_{50}$ (or $\left.\mathrm{LC}_{50}\right)$ :

$$
\mathrm{TU}=\frac{100}{\% \mathrm{EC}_{50}} .
$$

If the mortality in a $100 \%$ effluent concentration was between $10 \%$ and $49 \%$, the TUs were derived as follows:

$$
\mathrm{TU}=0.02 \times \% \text { mortality }
$$

A toxic unit of zero was allocated to mortalities between $0 \%$ and $10 \%$ in $100 \%$ effluent exposure $[25,26]$.

$1 \%$ amendment of landfill leachate in wastewater stream slightly increased whole influent toxicity (Table 7). Significant differences versus system III are observed only towards 
TABLE 7: Results of landfill leachate toxicity tests (average values from three experiments).

\begin{tabular}{|c|c|c|c|c|}
\hline \multirow[t]{2}{*}{ Organism } & \multicolumn{2}{|c|}{ Old landfill leachate } & \multicolumn{2}{|c|}{ New landfill leachate } \\
\hline & $\mathrm{EC} \mathrm{IC}_{50}[\%]$ & $\mathrm{TU} \pm \mathrm{SD}$ & $\mathrm{EC} / \mathrm{IC}_{50}[\%]$ & $\mathrm{TU} \pm \mathrm{SD}$ \\
\hline Thamnocephalus platyurus & $98 \pm 7.0$ & $1.0 \pm 0.1$ & $1.4 \pm 0.2$ & $71.4 \pm 9.0$ \\
\hline Daphnia magna & $\max$. effect $35 \% \pm 3.0$ & $0.7 \pm 0.06$ & $2.6 \pm 0.6$ & $38.5 \pm 9.2$ \\
\hline Vibrio fischeri & $28 \pm 5.6$ & $3.6 \pm 0.7$ & $2.8 \pm 0.3$ & $36.0 \pm 4.0$ \\
\hline Raphidocelis subcapitata & $67 \pm 13.4$ & $1.5 \pm 0.3$ & $3.0 \pm 0.3$ & $34.0 \pm 3.7$ \\
\hline
\end{tabular}

TABLE 8: Toxicity of raw and treated wastewater (1\% of leachate in influent I and II; the $95 \%$ confidence limit in parenthesis).

\begin{tabular}{|c|c|c|c|c|c|c|}
\hline \multirow{2}{*}{ Organism } & \multirow{2}{*}{$\begin{array}{l}\text { Number of } \\
\text { tests }\end{array}$} & \multirow{2}{*}{ System } & \multicolumn{2}{|l|}{ Influent } & \multicolumn{2}{|l|}{ Effluent } \\
\hline & & & Average $\mathrm{EC}_{50}[\%] \pm \mathrm{SD}$ & $\mathrm{TU}$ & Average $\mathrm{EC}_{50}[\%] \pm \mathrm{SD}$ & $\mathrm{TU}$ \\
\hline \multirow{3}{*}{ Daphnia magna } & 5 & I & $33.0(23.3-42.7)$ & $3.2 \pm 0.8$ & h.e. $<10 \%$ & 0 \\
\hline & 5 & II & $25.5(22.6-28.7)^{*}$ & $4.0 \pm 0.5$ & h.e. $<10 \%$ & 0 \\
\hline & 5 & III & $36.3(28.4-44.2)$ & $2.8 \pm 0.6$ & h.e. $<10 \%$ & 0 \\
\hline \multirow{3}{*}{ Thamnocephalus platyurus } & 5 & I & $18.0(10.1-25.9)$ & $7.2 \pm 4.4$ & h.e. $<10 \%$ & 0 \\
\hline & 5 & II & $16.3(10.1-22.5)$ & $7.9 \pm 4.0$ & h.e. $<10 \%$ & 0 \\
\hline & 5 & III & $18.8(16.4-21.2)$ & $7.5 \pm 4.2$ & 0 & 0 \\
\hline \multirow{3}{*}{ Raphidocelis subcapitata } & 5 & I & $67.0(53.9-80.1)^{*}$ & $1.5 \pm 0.3$ & \multirow{3}{*}{ Growth stimulation } & 0 \\
\hline & 5 & II & $44.0(28.7-59.2)$ & $2.6 \pm 1.0$ & & 0 \\
\hline & 5 & III & $54.0(42.4-65.6)$ & $1.9 \pm 0.6$ & & 0 \\
\hline \multirow{3}{*}{ Vibrio fischeri } & 5 & $\mathrm{I}$ & $23.5(19.2-27.9)$ & $4.3 \pm 0.6$ & h.e. $20 \% *$ & $0.4 \pm 0.2$ \\
\hline & 5 & II & $24.3(19.9-28.6)^{*}$ & $4.2 \pm 0.6$ & $91.5(80.1-102.9)^{*}$ & $0.8 \pm 0.5$ \\
\hline & 5 & III & $21.0(14.8-27.2)$ & $5.0 \pm 1.2$ & 0 & 0 \\
\hline
\end{tabular}

h.e.: highest observed effect for nondiluted sample.

* Indicate significant differences versus control III (Students $t$-test, $P<0.05$ ).

Daphnia magna (system II) and Raphidocelis subcapitata (system I). TU values of all influents towards tested organisms were below 10; therefore, influents were classified as toxic. After biological treatment, significant reduction of toxicity was observed. Slight residual toxicity of effluent was observed only for $V$. fischeri (system I and II). All effluents stimulated growth of algae due to still high content of nutrients (nitrate and phosphates).

Important increase of toxicity was observed in all tested bioassays while $10 \%$ of new landfill leachate was mixed with municipal wastewater (system II). 10\% of old landfill leachate in wastewater stream resulted in important increase of influent toxicity towards T. platyurus and V. fischeri. Toxicity of wastewater was successfully removed during biological treatment. Significant reduction of toxicity was also observed for effluent of system II, while effluent of system I was still characterized by important residual toxicity (except for $R$. subcapitata, where growth stimulation was observed).

Average TU values of leachate from new landfill were about 10 times higher than TU values obtained for leachate from old landfill. However, while $10 \%$ of leachate was mixed with municipal wastewater, toxicity of systems I and II influents was at similar level (Table 8). The reason of that phenomenon is that dose-response curve is usually nonlinear. Increasing toxic factor concentration might not result in similar increase of organisms' response. Similar effect was observed by Bortolotto et al. [27], where only slight, insignificant change of Allium cepa root length inhibition was attributed to increase of leachate concentration within the range of $40-80 \%$. The same authors also pointed that acute toxicity of treated leachate to Artemia salina was very low in a range of $10-80 \%$, even though nondiluted leachate effected in $80 \%$ mortality of crustacean. Also Bialowiec et al. [28] did not observe significant changes in Salix amygdalina leaf length and weight, despite exposition to landfill leachate concentration within the range of $0-12.5 \%$. In the present study, battery of bioindicators was exposed to mixture of landfill leachate and raw wastewater. During the study, toxicity of wastewater and leachate was changing due to natural fluctuations in those samples' composition. It is commonly accepted that interaction between mixture components may result in antagonist or synergetic effects which cannot be solely predicted at the base of initial toxicity data of elements or chemical species.

Acute toxicity of landfill leachate is often attributed to high ammonium nitrogen concentration $[6,29,30]$. In the present study, however, residual toxic effect was observed for system I effluent towards 3 (out of 4) tested organisms even though ammonium nitrogen was successfully removed during biological treatment. In that case residual toxicity of system I treated wastewater was caused by recalcitrant organic compounds, which were not removed during the treatment. Biological cotreatment of leachate from old landfill 
TABLE 9: Toxicity of raw and treated wastewater (10\% of leachate in influent I and II; the 95\% confidence limit in parenthesis).

\begin{tabular}{|c|c|c|c|c|c|c|}
\hline \multirow{2}{*}{ Organism } & \multirow{2}{*}{$\begin{array}{l}\text { Number of } \\
\text { tests }\end{array}$} & \multirow{2}{*}{ System } & \multicolumn{2}{|c|}{ Influent } & \multicolumn{2}{|c|}{ Effluent } \\
\hline & & & Average $\mathrm{EC}_{50}[\%]$ & $\mathrm{TU} \pm \mathrm{SD}$ & Average $\mathrm{EC}_{50}[\%]$ & $\mathrm{TU} \pm \mathrm{SD}$ \\
\hline \multirow{3}{*}{ Daphnia magna } & 5 & I & $32(15.2-48.8)$ & $4.3 \pm 3.1$ & h.e. $28 \%$ & $0.6 \pm 0.2$ \\
\hline & 5 & II & $23.6(21.7-25.5)^{*}$ & $4.3 \pm 0.4$ & 0 (h.e. $<10 \%)$ & 0 \\
\hline & 5 & III & $43.7(38.1-49.3)$ & $2.3 \pm 0.3$ & 0 & 0 \\
\hline \multirow{3}{*}{ Thamnocephalus platyurus } & 5 & I & $10.6(7.8-13.4)^{*}$ & $10.7 \pm 4.1$ & $84(76.9-91.1)^{*}$ & $1.1 \pm 0.2$ \\
\hline & 5 & II & $10.7(9.4-12.0)^{*}$ & $9.4 \pm 1.1$ & $0($ h.e. $<10 \%)$ & 0 \\
\hline & 5 & III & $19.8(17.3-22.3)$ & $5.1 \pm 0.7$ & 0 & 0 \\
\hline \multirow{3}{*}{ Raphidocelis subcapitata } & 5 & $\mathrm{I}$ & $57.0(47.5-66.5)$ & $1.8 \pm 0.3$ & \multirow{3}{*}{ Growth stimulation } & 0 \\
\hline & 5 & II & $32.3(31.6-33.0)^{*}$ & $3.2 \pm 0.8$ & & 0 \\
\hline & 5 & III & $55.0(52.1-57.9)$ & $1.8 \pm 0.1$ & & 0 \\
\hline \multirow{3}{*}{ Vibrio fischeri } & 3 & $\mathrm{I}$ & $17.1(11.3-22.9)^{*}$ & $6.2 \pm 1.4$ & $55.9(30.7-80.3)^{*}$ & $1.8 \pm 0.5$ \\
\hline & 3 & II & $15.3(12.2-18.4)^{*}$ & $6.6 \pm 1.1$ & $87.3(82.1-92.5)^{*}$ & $1.1 \pm 0.1$ \\
\hline & 3 & III & $30.3(27.2-33.4)$ & $3.3 \pm 0.3$ & 0 & 0 \\
\hline
\end{tabular}

h.e.: highest observed effect for nondiluted sample.

*Indicates significant differences versus control-III (Students $t$-test, $P<0.05$ ).

and municipal wastewater could not be, therefore, suggested as safe method for landfill leachate toxicity reduction.

In case of leachate from new landfill-at the base of present and some previous studies [31, 32]—dose-response curve was derived for biologically cotreated leachate:

$$
y=0.7752 \cdot e^{0.0681 x}
$$

Investigation was performed for 1, 5, 10, and 15\% of new landfill leachate cotreated with municipal wastewater. After biological treatment, toxic response of effluents significantly differed from the control for wastewater containing 5, 10, and $15 \%$. of leachate. The maximum concentration of leachate, which, after biological cotreatment, would not be hazardous for more than $5 \%$ of species, could be roughly assessed with use of safety factors. For the toxicity measurement, except from Raphidocelis subcapitata growth inhibition test, only acute toxicity tests were performed. Moreover, small group of 4 organisms served as biotest battery. Therefore, counting the hazardous concentration of landfill leachate, safety factor of 100 should be used. The highest leachate concentration, which after biological treatment would not be harmful for $95 \%$ of aquatic species, is $0.05 \%$.

\section{Conclusions}

Landfill leachate significantly disrupts biological treatment of wastewater. After biological treatment, wastewater enriched with $10 \%$ leachate did not meet the water quality standards and still was harmful to aquatic organisms.

The calculated concentration of new landfill leachate, which after biological treatment would not be harmful for aquatic organisms, was $0.05 \%$.

\section{Acknowledgment}

The author would like to thank MSc Magdalena Wierciak for her technical support. The research was supported by the Grant BW 504/RIE-8/2010.

\section{References}

[1] Z. Salem, K. Hamouri, R. Djemaa, and K. Allia, "Evaluation of landfill leachate pollution and treatment," Desalination, vol. 220, no. 1-3, pp. 108-114, 2008.

[2] S. Renou, J. G. Givaudan, S. Poulain, F. Dirassouyan, and P. Moulin, "Landfill leachate treatment: Review and opportunity," Journal of Hazardous Materials, vol. 150, no. 3, pp. 468493, 2008.

[3] EEC, "Council Directive on the landfill of waste," 99/31/EEC, 1999.

[4] Y. Deguchi, T. Toyoizumi, S. Masuda et al., "Evaluation of mutagenic activities of leachates in landfill sites by micronucleus test and comet assay using goldfish," Mutation Research, vol. 627, no. 2, pp. 178-185, 2007.

[5] Y. D. Kim and D. G. Lee, "Comparative study on leachate in closed landfill sites: focusing on seasonal variations," Journal of Material Cycles and Waste Management, vol. 11, no. 3, pp. 174-182, 2009.

[6] M. Isidori, M. Lavorgna, A. Nardelli, and A. Parrella, “Toxicity identification evaluation of leachates from municipal solid waste landfills: a multispecies approach," Chemosphere, vol. 52, no. 1, pp. 85-94, 2003.

[7] M. Bodzek, J. Surmacz-Górska, and Y. Hung, "Treatment of landfill leachate," in Handbook of Industrial and Hazardous Wastes Treatment, L. Wang, Y. Hung, and C. Yapijakis, Eds., Marcel Dekker, New York, NY, USA, 2004.

[8] E. Benfenati, E. Porazzi, R. Bagnati et al., "Organic tracers identification as a convenient strategy in industrial landfills monitoring," Chemosphere, vol. 51, no. 8, pp. 677-683, 2003.

[9] Z. Yang and S. Zhou, "The biological treatment of landfill leachate using a simultaneous aerobic and anaerobic (SAA) 
bio-reactor system," Chemosphere, vol. 72, no. 11, pp. 17511756, 2008.

[10] H. Zhang, H. J. Choi, and C. P. Huang, "Effects of important reaction conditions on landfill leachate treatment by Fenton process," Fresenius Environmental Bulletin, vol. 15, no. 1, pp. 43-47, 2006.

[11] H. Zhang, Z. Cheng, and D. Zhang, "Treatment of landfill leachate by electro-fenton process," Fresenius Environmental Bulletin, vol. 16, no. 9, pp. 1216-1219, 2007.

[12] A. Białowiec, "The rational management of landfill leachate," Przeglad Komunalny, vol. 10, pp. 30-35, 2009 (Polish).

[13] J. Szyc, Leachate from Municipal Landfills, Institute of Environmental Protection, Warsaw, Poland, 2003.

[14] Oznaczanie Chemicznego Zapotrzebowania Tlenu (ChZT) Metodą Dwuchromianową, "Badanie zapotrzebowania tlenu i zawartości węgla organicznego," Tech. Rep. PN-74 C04578/03, Oznaczanie Chemicznego Zapotrzebowania Tlenu (ChZT) Metodą Dwuchromianową, 2003.

[15] Metoda do Próbek Nierozcieńczonych, "Oznaczenie biochemicznego zapotrzebowania tlenu po n dniach,” Tech. Rep. PNEN 1899-2, Metoda do Próbek Nierozcieńczonych, Część 2, 2002.

[16] Azur Environment, Microtox-Standard Operational Procedure, Azur Environment, 1991.

[17] ISO 6341, "Water quality_-determination of the inhibition of the mobility of Daphnia magna Straus (Cladocera, Crustacea)—acute toxicity test," 1996.

[18] MicroBioTest, Thamnotoxkit Standard Operational Procedure, 1998.

[19] ISO 8692, "Water quality Freshwater algal growth inhibition test with unicellular green algae," 2004.

[20] EEC, "Urban Wastewater Treatment Directive," 91/271/EEC, 1991.

[21] Dz.U. no 137, "Rozporza̧dzenie Ministra Środowiska z dnia 24 lipca 2006 w sprawie warunków jakie należy spełnić przy wprowadzaniu ścieków do wód lub do ziemi, oraz w sprawie substancji szczególnie szkodliwych dla środowiska wodnego," 2006.

[22] E. Diamadopoulos, P. Samaras, X. Dabou, and G. P. Sakellaropoulos, "Combined treatment of landfill leachate and domestic sewage in a sequencing batch reactor," Water Science and Technology, vol. 36, no. 2-3, pp. 61-68, 1997.

[23] R. He, X. W. Liu, Z. J. Zhang, and D. S. Shen, "Characteristics of the bioreactor landfill system using an anaerobic-aerobic process for nitrogen removal," Bioresource Technology, vol. 98, no. 13, pp. 2526-2532, 2007.

[24] C. Y. Gomec, D. I. Cifci, I. Ozturk, and C. Kinaci, "Combined anaerobic treatment of domestic wastewater and landfill leachate at psychrophilic temperatures," Fresenius Environmental Bulletin, vol. 17, no. 11, pp. 1828-1832, 2008.

[25] G. Persoone, B. Marsalek, I. Blinova et al., "A practical and user-friendly toxicity classification system with microbiotests for natural waters and wastewaters," Environmental Toxicology, vol. 18, no. 6, pp. 395-402, 2003.

[26] J. S. Ra, B. C. Lee, N. I. Chang, and S. D. Kim, "Comparative whole effluent toxicity assessment of wastewater treatment plant effluents using Daphnia magna," Bulletin of Environmental Contamination and Toxicology, vol. 80, no. 3, pp. 196-200, 2008.

[27] T. Bortolotto, J. B. Bertoldo, F. Z. D. Silveira, T. M. Defaveri, J. Silvano, and C. T. Pich, "Evaluation of the toxic and genotoxic potential of landfill leachates using bioassays," Environmental Toxicology and Pharmacology, vol. 28, no. 2, pp. 288-293, 2009.
[28] A. Bialowiec, P. F. Randerson, and M. Kopik, "Using fractal geometry to determine phytotoxicity of landfill leachate on willow," Chemosphere, vol. 79, no. 5, pp. 534-540, 2010.

[29] S. K. Marttinen, R. H. Kettunen, K. M. Sormunen, R. M. Soimasuo, and J. A. Rintala, "Screening of physical-chemical methods for removal of organic material, nitrogen and toxicity from low strength landfill leachates," Chemosphere, vol. 46, no. 6, pp. 851-858, 2002.

[30] G. Dave and E. Nilsson, "Increased reproductive toxicity of landfill leachate after degradation was caused by nitrite," Aquatic Toxicology, vol. 73, no. 1, pp. 11-30, 2005.

[31] J. Kalka, A. Ośliślok, J. Surmacz-Górska, K. Krajewska, D. Marciocha, and A. Raszka, "A laboratory study on toxicity removal from landfill leachate In combined treatment with municipal wastewater," in Environmental Engineering III, pp. 185-189, Taylor \& Francis, London, UK, 2010.

[32] J. Kalka, "Changes in ecotoxicological hazard during biological treatment of municipal waste landfills" (Polish), Rapport, unpublished. 


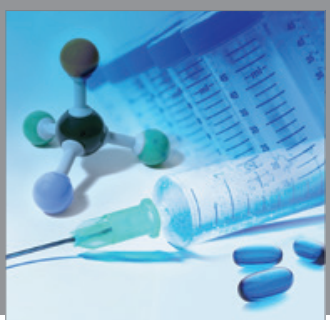

International Journal of

Medicinal Chemistry

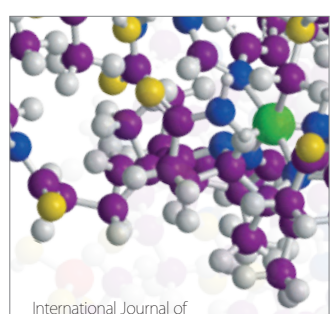

Carbohydrate Chemistry

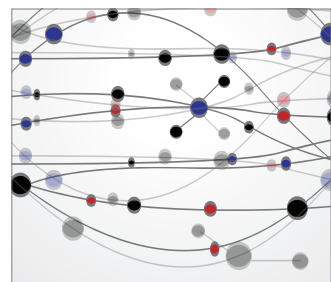

The Scientific World Journal
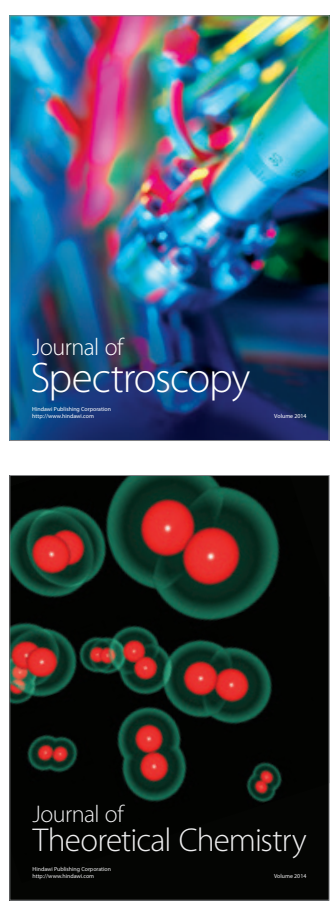
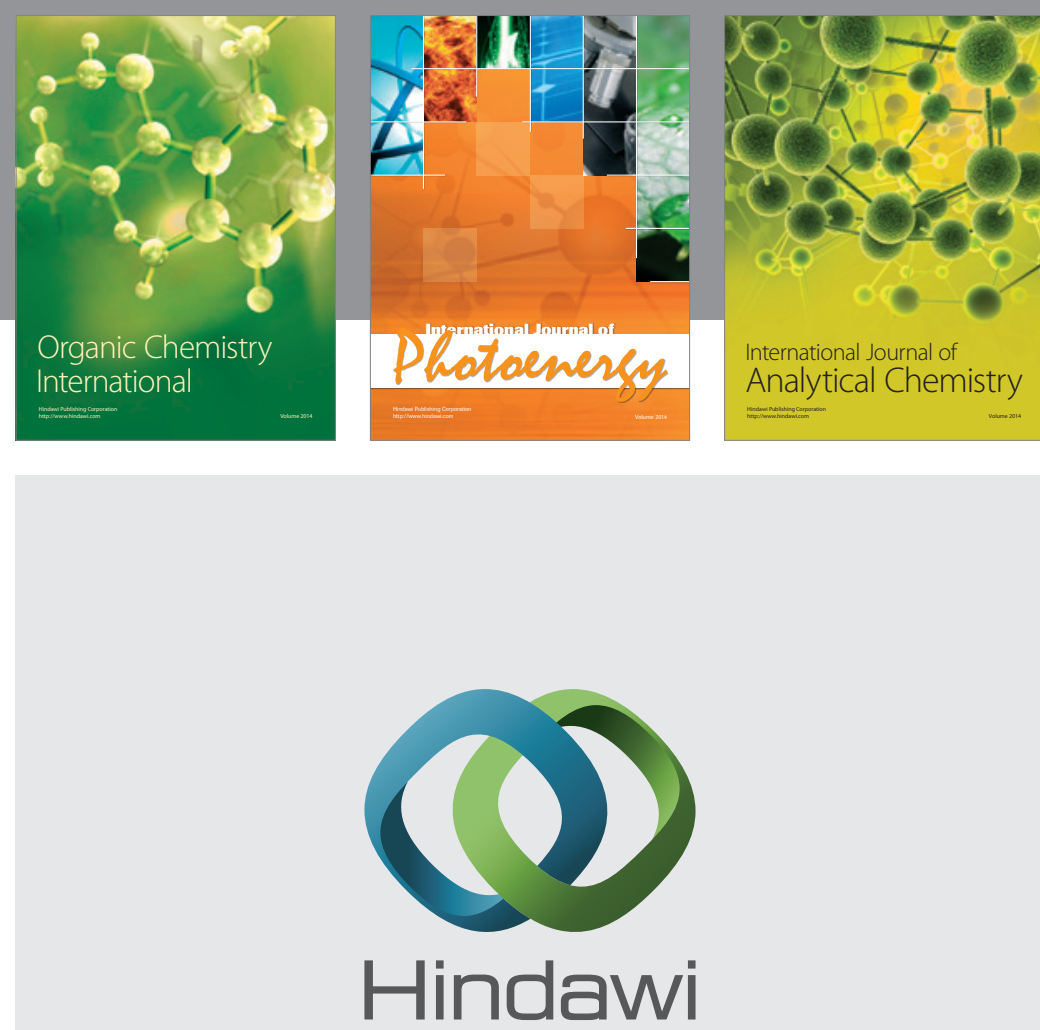

Submit your manuscripts at

http://www.hindawi.com
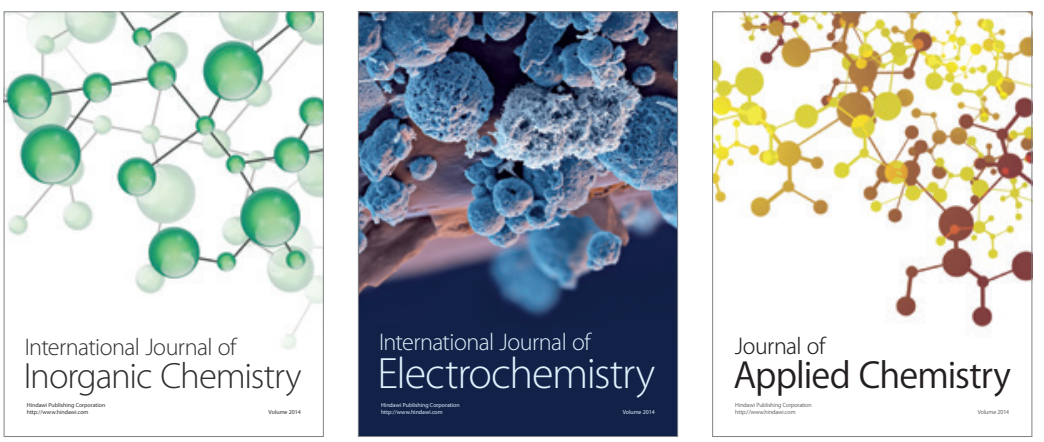

Journal of

Applied Chemistry
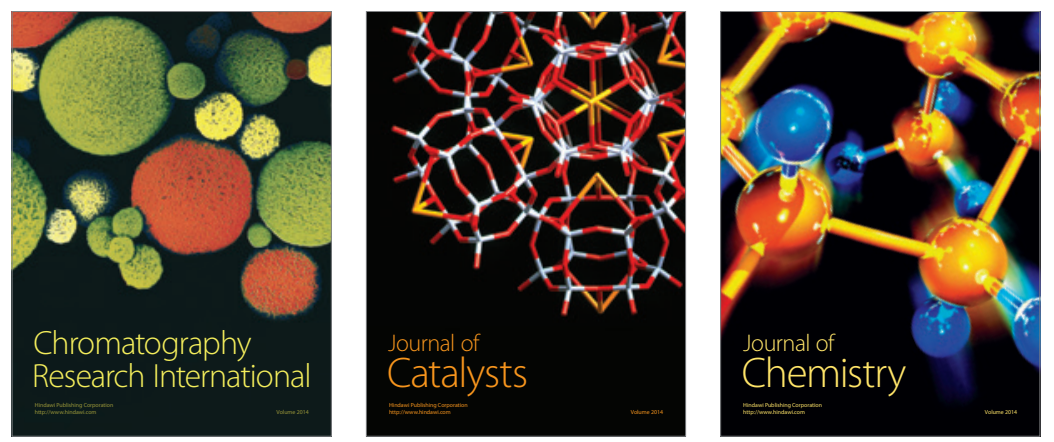
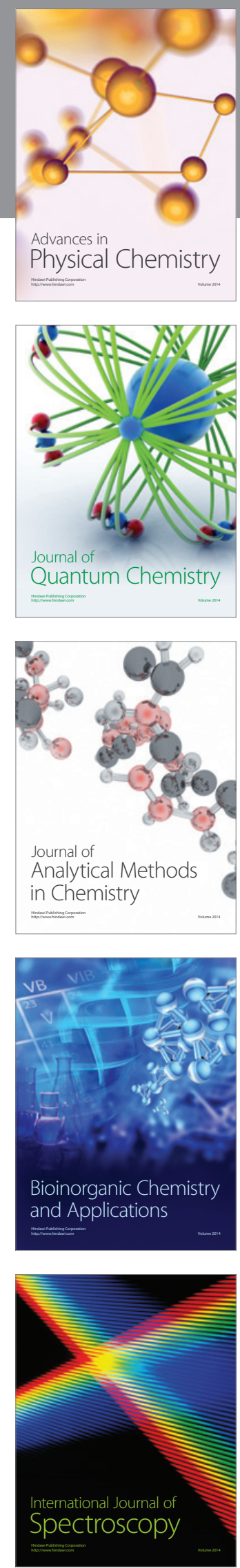